\title{
The POP1 gene encodes a protein component common to the RNase MRP and RNase $P$ ribonucleoproteins
}

\author{
Zoi Lygerou, Philip Mitchell, Elisabeth Petfalski, Bertrand Séraphin, and David Tollervey \\ European Molecular Biology Laboratory (EMBL), 69012 Heidelberg, Germany
}

Two forms of the yeast 5.8S rRNA are generated from a large precursor by distinct processing pathways. Cleavage at site $A 3$ is required for synthesis of the major, short form, designated $5.8 \mathrm{~S}(\mathrm{~S})$, but not for synthesis of the long form, $5.8 \mathrm{~S}(\mathrm{~L})$. To identify components required for A3 cleavage, a bank of temperature-sensitive lethal mutants was screened for those with a reduced ratio of $5.8 \mathrm{~S}(\mathrm{~S}): 5.8 \mathrm{~S}(\mathrm{~L})$. The pop 1-1 mutation (for processing of precursor RNAs) shows this phenotype and also inhibits A3 cleavage. The pre-rRNA processing defect of pop1-1 strains is similar to that reported for mutations in the RNA component of RNase MRP; we show that a mutation in the RNase MRP RNA also inhibits cleavage at site A3. This is the first site shown to require RNase MRP for cleavage in vivo. The pop1-1 mutation also leads to a block in the processing of pre-tRNA that is identical to that reported for mutations in the RNA component of RNase P. The RNA components of both RNase MRP and RNase $P$ are underaccumulated in pop 1-1 strains at the nonpermissive temperature, and immunoprecipitation demonstrates that POP1p is a component of both ribonucleoproteins. The POP1 gene encodes a protein with a predicted molecular mass of $100.5 \mathrm{kD}$ and is essential for viability. POP1p is the first protein component of the nuclear RNase P or RNase MRP for which the gene has been cloned.

[Key Words: POP1 gene; RNase MRP; RNase P; S. cerevisiae; RNA processing]

Received April 4, 1994; revised version accepted May 9, 1994.

Two ribonucleoprotein (RNP) complexes are known to have endoribonuclease (RNase) activity. These are the RNase $\mathrm{P}$ and RNase mitochondrial RNA processing (MRP) RNPs.

All pre-tRNAs are transcribed with $5^{\prime}$ and $3^{\prime}$ extensions, and some contain intervening sequences that are removed to produce the mature tRNAs. RNase $P$ is responsible for the $5^{\prime}$ processing of pre-tRNAs in eubacteria, archaebacteria, and eukaryotes (for review, see Altman 1989; Darr et al. 1992; Altman et al. 1993). RNase P also processes the precursor of the 4.5S RNA in Escherichia coli (for review, see by Altman et al. 1993) but has not been reported to have substrates other than pretRNAs in archaebacteria or eukaryotes. The RNA component of eubacterial RNase $P$ has catalytic activity in vitro in the absence of protein cofactors. In contrast, the RNA components of archaebacterial (Nieuwlandt et al. 1991; LaGrandeur et al. 1993) and eukaryotic RNase P have not been found to be catalytic in the absence of proteins, despite their considerable structural homology to the eubacterial RNAs. E. coli RNase P contains a single protein, designated $\mathrm{C} 5$, which is small (119 amino acids, $13.8 \mathrm{kD}$ ) and highly basic. This protein cofactor is required for RNase $\mathrm{P}$ activity in vivo and greatly stimulates activity in vitro. The protein plays important roles in the release of the product, the mature tRNA, from the enzyme, which is the rate-limiting step for the RNA catalyzed reaction in vitro (Reich et al. 1988; Tallsjö and Kirsebom 1993), and in the binding of suboptimal substrates, including the 4.5S RNA (Peck-Miller and Altman 1991; for review, see Altman et al. 1993). The Bacillus subtilis RNase $\mathrm{P}$ contains a protein, $\mathrm{P}$ protein, which is of similar size to C5 but only $25 \%$ identical. Despite this low homology, C5 and P proteins will reconstitute RNase $\mathrm{P}$ holoenzymes with the heterologous RNAs, showing that their binding sites and functions have been conserved (Guerrier-Takada et al. 1983; for review, see Altman et al. 1993).

The major RNase P RNA in the budding yeast Saccharomyces cerevisiae is 369 nucleotides in length; less abundant $5^{\prime}$ and $3^{\prime}$ extended forms are also detected and may represent precursors (Lee et al. 1991). S. cerevisiae RNase P RNA is encoded by the RPR1 gene, which is essential for viability. A temperature-sensitive mutant of rpr1 accumulates pre-tRNAs that are spliced but $5^{\prime}$ and $3^{\prime}$ unprocessed (Lee et al. 1991). Analysis of the protein components of the nuclear RNase P from $S$. cerevisiae has not been reported; however, highly purified RNase P from Schizosaccharomyces pombe contains a single protein component of $100 \mathrm{kD}$ estimated molecular mass (Zimmerly et al. 1993). RNase P from vertebrates can be immunoprecipitated by human Th autoim- 
mune sera (also called To sera) (Gold et al. 1989). These sera also precipitate a protein of $40 \mathrm{kD}$ estimated molecular mass (for review, see Reimer et al. 1987), as well as several other polypeptides (Gold et al. 1989). Surprisingly, anti-Th sera from many different patients also precipitate another RNP particle, RNase MRP (or Th RNP), which has been taken to show that human RNase P and RNase MRP share at least one antigenic epitope or common polypeptide (Gold et al. 1989).

RNase MRP was identified and purified from both vertebrates and yeast using an in vitro assay for the cleavage of RNA transcribed from the mitochondrial DNA at a position close to the site of formation of the primer for mitochondrial DNA replication (Chang and Clayton 1987; Stohl and Clayton 1992). Both the RNA component, MRP RNA or 7-2 RNA, and the Th antigenic peptide are, however, localized predominantly in the nucleolus (Reimer et al. 1987, 1988; Yuan et al. 1989; Kiss et al. 1992; Topper et al. 1992), indicating that RNase MRP may also have a role in pre-rRNA processing. Both RNase P and endonuclease G have also been reported to cleave the mitochondrial RNA in vitro at some of the sites cleaved by RNase MRP (Côté and Ruiz-Carrillo 1993; Potuschak et al. 1993). The RNA components of RNase P and MRP have considerable structural homology, with a conserved core region termed the cage structure (for review, see Altman 1989; Darr et al. 1992; Altman et al. 1993; Karwan 1993; Schmitt et al. 1993). This, together with the existence of a common epitope or polypeptide, suggests that these RNPs have substantial similarities.

Yeast RNase MRP RNA is 340 nucleotides in length and is encoded by the NME1 gene, which is essential for viability (Schmitt and Clayton 1992; Stohl and Clayton 1992). A previously identified gene, $R R P 2$, has been reported recently to be allelic with NME1 (Chu et al. 1994). Depletion of RNase MRP by repression of the NME1 gene placed under the control of a $G A L$ promoter, as well as temperature-sensitive alleles of nme1 (rrp2), affect pre-rRNA processing (Shuai and Warner 1991; Lindahl et al. 1992; Schmitt and Clayton 1993).

The yeast $18 \mathrm{~S}, 5.8 \mathrm{~S}$, and $25 \mathrm{~S}$ rRNAs are cotranscribed as a large $35 \mathrm{~S}$ rRNA precursor (Fig. 1A) that undergoes a series of cleavage and modification steps in the nucleolus to generate the mature rRNAs (Fig. 1B). The mature yeast $5.8 \mathrm{~S}$ rRNA is heterogeneous at its $5^{\prime}$ end (Rubin 1974) with a major short form, designated $5.8 \mathrm{~S}(\mathrm{~S})$ and a minor form, 7-8 nucleotides longer, designated $5.8 \mathrm{~S}(\mathrm{~L})$. The $5.8 \mathrm{~S}(\mathrm{~S})$ and $5.8 \mathrm{~S}(\mathrm{~L})$ rRNAs do not have a precursor/ product relationship but are formed by distinct processing pathways (Amberg et al. 1992; Schmitt and Clayton 1993; Henry et al. 1994). The $5^{\prime}$ end of the major $5.8 \mathrm{~S}(\mathrm{~S})$ RNA is generated by exonucleases that digest $5^{\prime} \rightarrow 3^{\prime}$ from site A3 in internal transcribed spacer 1 (ITS1) (see Fig. $1 \mathrm{~B})$, and the synthesis of $5.8 \mathrm{~S}(\mathrm{~S})$ is therefore inhibited by mutations in the pre-rRNA that prevent $\mathrm{A} 3$ cleavage (Henry et al. 1994). In contrast, formation of the $5.8 \mathrm{~S}(\mathrm{~L})$ rRNA does not require cleavage at site A3. The rrp2-1 and nme1 mutants show defects in pre-rRNA processing, including the underaccumulation of the $5.8 \mathrm{~S}(\mathrm{~S}) \mathrm{rRNA}$
A

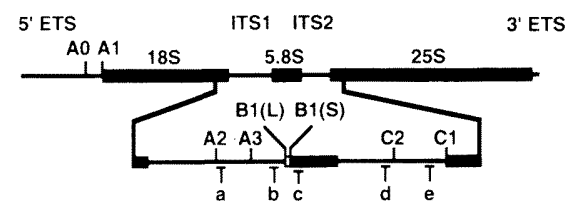

B

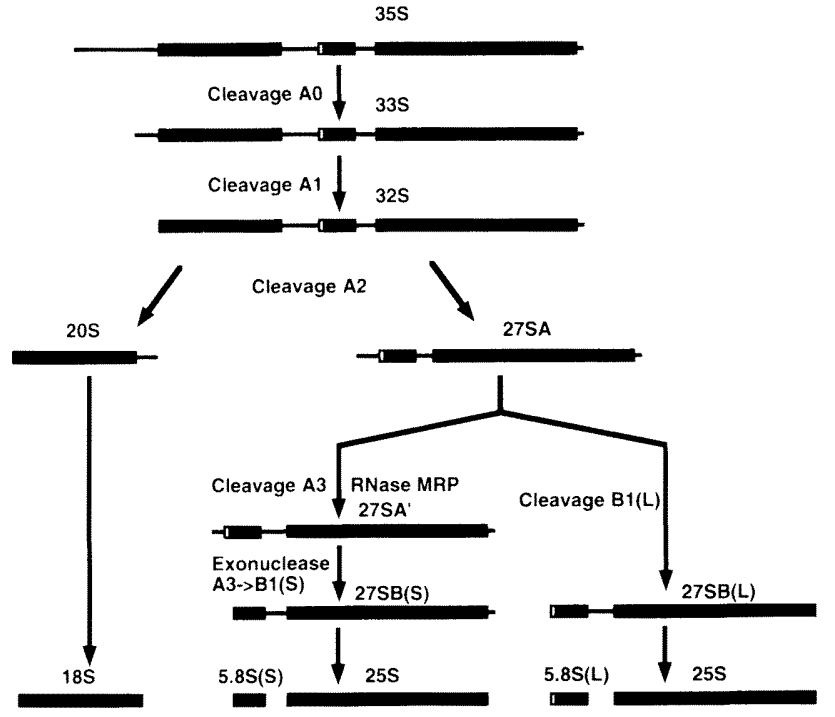

Figure 1. Structure and processing of the yeast pre-rRNA. $(A)$ Structure of the $35 \mathrm{~S}$ pre-rRNA. Locations of the pre-rRNA cleavage sites (uppercase). Oligonucleotides used for Northern hybridization and primer extension (lowercase) are shown. $(B)$ Pre-rRNA processing pathway. The $35 \mathrm{~S}$ pre-rRNA undergoes snoRNP-dependent cleavages at site A0 in the 5' ETS (generating the $33 \mathrm{~S}$ pre-rRNA), site Al at the $5^{\prime}$ end of the $18 \mathrm{~S}$ rRNA (generating $32 \mathrm{~S}$ pre-rRNA) and A2 in ITS1 (generating the 20S and 27SA pre-rRNAs|. A2 cleavage separates the pre-rRNAs destined to form the small and large ribosomal subunits. The $20 \mathrm{~S}$ pre-rRNA is cleaved, probably endonucleolytically, to generate the $18 \mathrm{~S}$ rRNA. The $27 \mathrm{SA}$ pre-rRNA can be processed by two alternative pathways. In the major pathway, 27SA is cleaved by RNase MRP at site A3 to generate the $27 \mathrm{SA}^{\prime}$ pre-rRNA. A3 acts as an entry site for an exonuclease activity that degrades the pre-rRNA $5^{\prime} \rightarrow 3^{\prime}$ to site $\mathrm{Bl} / \mathrm{S}$ ) generating the $5^{\prime}$ end of the short form of the $27 \mathrm{SB}$ pre-rRNA, $27 \mathrm{SB}(\mathrm{S})$. This pre-rRNA is subsequently processed to the $5.8 \mathrm{~S}(\mathrm{~S})$ and $25 \mathrm{~S}$ rRNAs. An alternative pathway leads to cleavage at site $\mathrm{Bl} \mid \mathrm{L})$, the $5^{\prime}$ end of the $27 \mathrm{SB}(\mathrm{L})$ pre-rRNA, which is processed to yield the $5.8 \mathrm{~S}(\mathrm{~L})$ and $25 \mathrm{~S} \mathrm{rR}$ NAs. For simplicity, details of the processing of $27 \mathrm{SB}$ to $5.8 \mathrm{~S}$ and $25 \mathrm{~S}$ are not shown. It is not clear whether the 33S RNA is an intermediate in the major processing pathway, and the precise timing of the cleavage of the short $3^{\prime}$ ETS sequence is not known

and the accumulation of a $5^{\prime}$ extended form of $5.8 \mathrm{~S}$ rRNA that extends into ITS1 to pre-rRNA cleavage site A2 (see Fig. 1B) (Shuai and Warner 1991; Lindahl et al. 1992; Schmitt and Clayton 1993). This suggests the involvement of RNase MRP in the formation of the $5.8 \mathrm{~S}(\mathrm{~S})$ rRNA.

To identify components specifically inhibited in cleavage at site $\mathrm{A} 3$, we screened a bank of temperature-sensi- 
tive-lethal mutants for those that alter the ratio of $5.8 \mathrm{~S}(\mathrm{~L})$ to $5.8 \mathrm{~S}(\mathrm{~S})$ at the nonpermissive temperature. We obtained one mutant with this phenotype; the gene mutated, POP1 (for processing of precursor RNAs), encodes a common component of the RNase MRP and RNase P RNPs.

\section{Results}

Isolation of pop1-1, a temperature-sensitive mutation causing defects in both RNase $M R P$ and RNase $P$ functions

A bank of temperature-sensitive yeast mutants was generated by UV-mutagenizing haploid yeast cells to $5-15 \%$ survival. Following growth at $23^{\circ} \mathrm{C}$, surviving colonies were tested for growth at $37^{\circ} \mathrm{C}$. A total of 246 temperature-sensitive mutants were isolated.

To identify mutants that are altered in the ratio of $5.8 \mathrm{~S}(\mathrm{~L})$ to $5.8 \mathrm{~S}(\mathrm{~S})$, RNA was extracted from the 246 temperature-sensitive-lethal strains following growth for $2.5 \mathrm{hr}$ at the nonpermissive temperature. RNA was separated by polyacrylamide gel electrophoresis and transferred for Northern hybridization. The filters were hybridized with an oligonucleotide probe hybridizing within the $5.8 \mathrm{~S}$ rRNA-coding region (oligonucleotide $\mathrm{c}$, see Fig. 1A). One mutant strain was identified that underaccumulates $5.8 \mathrm{~S}(\mathrm{~S})$, but not $5.8 \mathrm{~S}(\mathrm{~L})$, and the mutation was designated pop 1-1.

At the permissive temperature $\left(23^{\circ} \mathrm{C}\right)$ synthesis of rRNA and tRNA by the pop1-1 strain (Fig. 2, lane 2) is similar to that of the POP1 strain (Fig. 2, lane 1). During growth at $37^{\circ} \mathrm{C}$, the pop $1-1$ strain underaccumulates the $5.8 \mathrm{~S}(\mathrm{~S})$ rRNA and has a mildly increased level of $5.8 \mathrm{~S}(\mathrm{~L})$ (Fig. 2, lanes 3-5). In the wild-type strain the ratio of $5.8 \mathrm{~S}(\mathrm{~L}) / 5.8 \mathrm{~S}(\mathrm{~S})$ is $\sim 1: 8$; this falls to $\sim 1: 1$ following growth of the pop1-1 strain for $20 \mathrm{hr}$ at $37^{\circ} \mathrm{C}$. Hybridization shows that the pop1-1 strain strongly accumulates a $5^{\prime}$ extended form of the 5.8S rRNA, which includes the $3^{\prime}$ region of ITS $1\left(5.8 \mathrm{~S}+\mathrm{ITS} 13^{\prime}\right)$ during growth at $37^{\circ} \mathrm{C}$ (Fig. 2, lanes 8-10, top right). This RNA hybridizes with an oligonucleotide complementary to the region of ITS1 immediately $3^{\prime}$ to site A2 (oligonucleotide a; see Fig. 1A) (Fig. 2, lanes 6-10, top right) and also with an oligonucleotide from within the mature $5.8 \mathrm{~S}$ region (oligonucleotide c; see Fig. 1A) (data not shown). The size and hybridization pattern of this RNA is consistent with its extending from cleavage site A2 to the $3^{\prime}$ end of the mature 5.8S rRNA. Such an RNA species would be generated if processing at site $\mathrm{A} 3$ was inhibited while processing in ITS2 continued (see Fig. 1B). This phenotype is the same as that reported for mutations in the RNA component of RNase MRP (Shuai and Warner 1991; Lindahl et al. 1992; Schmitt and Clayton 1993). The level of the 5S rRNA which, like 5.8S rRNA, is a component of the $60 \mathrm{~S}$ ribosomal subunit, is also reduced in the pop1-1 strain grown at $37^{\circ} \mathrm{C}$. The steady-state levels of several small nucleolar RNAs (snoRNAs) and small nuclear RNAs (snRNAs) are, however, not affected by growth of the pop1-1 strain at $37^{\circ} \mathrm{C}$ (see below; data not shown),

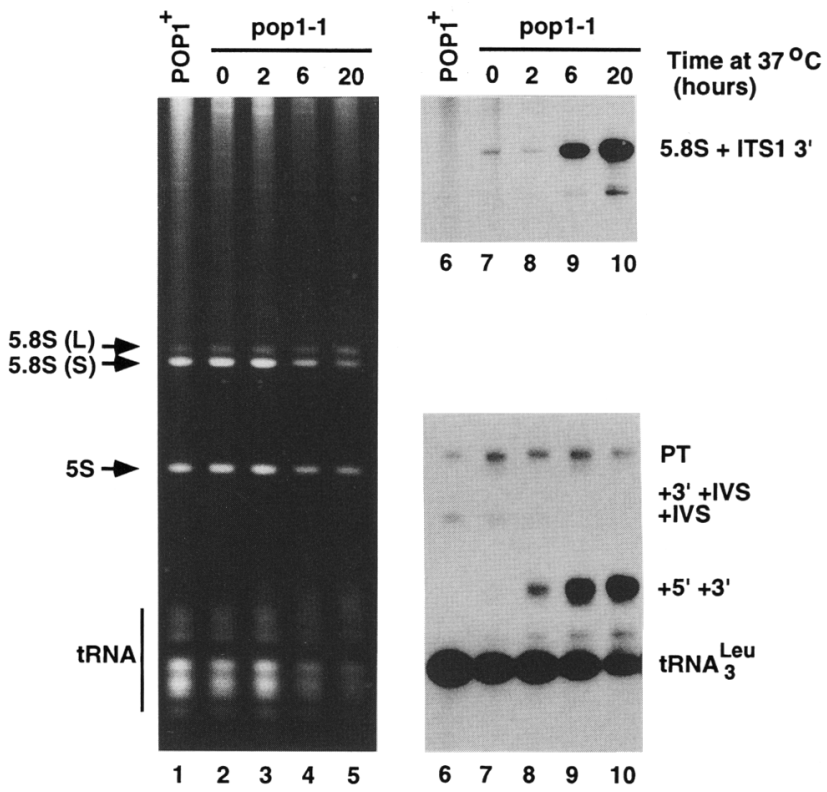

Figure 2. Effects of pop1-1 on 5.8S rRNA and tRNA synthesis. (Lanes 1-5) Staining of RNA with ethidium bromide. Lanes $6-10$, top) Northern hybridization with probe specific for the $3^{\prime}$ region of ITS1 (oligonucleotide a in Fig. 1); (bottom) Northern hybridization with probe specific for the mature region of tRNA $_{3}^{\text {Leu }}$. (Lanes 1,6$)$ RNA extracted from a wild-type POP1 ${ }^{+}$ strain following growth at $37^{\circ} \mathrm{C}$; (lanes 2,7) RNA extracted from a pop 1-1 strain following growth at $23^{\circ} \mathrm{C}$; (lanes $\left.3-5,8-10\right)$ RNA extracted from a pop1-1 strain following growth at $37^{\circ} \mathrm{C}$ for the times indicated. RNA extracted from $0.1 \mathrm{OD}_{600}$ unit of cells $\left(\sim 2 \times 10^{6}\right.$ cells $)$ was loaded in each lane. The position of the $5.8 \mathrm{~S}(\mathrm{~L}), 5.8 \mathrm{~S}(\mathrm{~S})$, and $5 \mathrm{~S}$ rRNAs and tRNAs are indicated. Also shown are the positions of the primary transcript of tRNA ${ }_{3}^{\text {Leu }}$ (PT), which is $5^{\prime}$ and $3^{\prime}$ extended and contains an IVS, and the pre-tRNA, which is $3^{\prime}$ extended and contains the IVS $1+3^{\prime}$ + IVS), 5' and $3^{\prime}$ mature but contains the IVS (+ IVS), spliced but $5^{\prime}$ and $3^{\prime}$ extended $\left(+5^{\prime}+3^{\prime}\right)$ and mature (tRNA $\left.{ }_{3}^{\text {Leu }}\right)$, as well as the $5^{\prime}$ extended form of $5.8 \mathrm{~S}$ rRNA $\left(5.8 \mathrm{~S}+\mathrm{ITS} 13^{\prime}\right)$. Note that the tRNAs are heterogeneous in size. The upper bands visible in the $P O P 1^{+}$strain are the larger tRNA species and not the pretRNAs, which cannot be observed by ethidium staining of RNA extracted from wild-type cells.

showing that the reduction in the levels of the mature rRNAs is not attributable to differences in RNA recovery.

In addition, the pop1-1 strain underaccumulates mature tRNAs at the nonpermissive temperature and a number of additional RNAs accumulate, the sizes of which are appropriate for pre-tRNAs (Fig. 2, lanes 3-5). Hybridization with probes to the mature tRNA ${ }_{3}^{\text {Leu }}$ (Fig. 2 , lanes $6-10$, bottom right), intervening sequence (IVS) and $5^{\prime}$ leader (data not shown), shows that at $23^{\circ} \mathrm{C}$ processing of the pre-tRNA is similar in the pop1-1 (Fig. 2, lane 7) and POP1 (Fig. 2, lane 6) strains. However, following growth of the pop $1-1$ strain at $37^{\circ} \mathrm{C}$, the $5^{\prime}-$ and $3^{\prime}$-unprocessed pre-tRNA $\left(+5^{\prime}+3^{\prime}\right)$ accumulates to very high levels (Fig. 2, lanes 8-10). After growth of the pop1-1 strain for $20 \mathrm{hr}$ at $37^{\circ} \mathrm{C}$, the $5^{\prime}$ - and $3^{\prime}$-unproc- 
essed pre-tRNA has accumulated to a level similar to that of the mature tRNA. In contrast, the levels of the pre-tRNA, which is unspliced but has been processed at the $5^{\prime}$ end (+IVS $+3^{\prime}$ ) or $5^{\prime}+3^{\prime}$ ends (+ IVS), are strongly reduced (these species are not easily visible at the exposure shown in Figure 2 and their levels were assessed on longer exposures; data not shown). The level of the primary transcript (PT) is little affected in the pop1-1 strain. This indicates that pre-tRNA splicing is not affected by the pop 1-1 mutation, but $5^{\prime}$ and $3^{\prime}$ processing is inhibited. This phenotype is identical to that reported for mutations in the RPR1 gene, which encodes the RNA component of RNase P (Lee et al. 1991). Hybridization with probes to the mature regions of two other spliced tRNAs, tRNA ${ }^{\text {ProUGG }}$ and tRNA ${ }^{\text {TrpCCA }}$, and two unspliced tRNAs, tRNA AlauGC and tRNA GlyGCC, showed that in each case the mature tRNAs are underaccumulated in the pop $1-1$ strain grown at $37^{\circ} \mathrm{C}$, whereas pre-tRNAs are strongly accumulated (data not shown).

From these results we conclude that the phenotype of the pop1-1 mutation resembles a combination of the phenotypes of mutations in the RNA components of RNase P and RNase MRP.

\section{pop1-1 and rrp2-1 mutants are inhibited in A3 cleavage}

Formation of the $5.8 \mathrm{~S}(\mathrm{~S})$ rRNA proceeds through cleavage at site $\mathrm{A} 3$, within the ITS1 region, which generates the $27 \mathrm{SA}^{\prime}$ pre-rRNA. This intermediate is then processed exonucleolytically to generate the $27 \mathrm{SB}|\mathrm{S}|$ prerRNA, which has the same $5^{\prime}$ end as the mature $5.8 \mathrm{~S}(\mathrm{~S})$ rRNA (Henry et al. 1994; see Fig. 1B).

Primer extension was used to assess whether pop 1-1 strains are defective in synthesis of the 27SA' pre-rRNA, which would indicate a block in A3 cleavage. Oligonucleotides hybridizing to the $3^{\prime}$ region of ITS1, the $5^{\prime}$ region of ITS2, and the $3^{\prime}$ region of ITS2 (oligonucleotides b, d, and e, respectively; see Fig. 1A) were used for primer extension (shown for oligonucleotide d in Fig. 3). In the POP1 control strain (Fig. 3, lane 1) and the pop1-1 strain following growth at $23^{\circ} \mathrm{C}$ (Fig. 3, lane 2), the 27SA' prerRNA is clearly detected. No primer extension stop at site A3 is detected in RNA transcribed in vitro (Fig. 3, lane 6), showing that this is not attributable to the secondary structure of the pre-rRNA. Following growth of the pop1-1 strain for $2 \mathrm{hr}$ at $37^{\circ} \mathrm{C}$, the level of $27 \mathrm{SA}^{\prime}$ pre-rRNA, shown by the level of the primer extension stop at site A3, is already strongly reduced (Fig. 3, lane 3). At this time point, other pre-rRNA processing reactions are not clearly inhibited in the pop1-1 strain (Fig. 3; data not shown). Growth of the pop 1-1 strain at $37^{\circ} \mathrm{C}$ for 6 or $20 \mathrm{hr}$, leads to further reduction in the level of $27 \mathrm{SA}^{\prime}$ pre-rRNA (Fig. 3, lanes 4,5). The level of 27SA pre-rRNA, which extends from A2 to the $3^{\prime}$ end of $25 \mathrm{~S}$ rRNA, as shown by the primer extension stop at site $\mathrm{A} 2$, is reduced only after prolonged growth of the pop $1-1$ strain at $37^{\circ} \mathrm{C}$ (Fig. 3, lane 5). The ratio between the long and short forms of the $27 \mathrm{SB}$ pre-rRNA [designated $27 \mathrm{SB}(\mathrm{L})$ and $27 \mathrm{SB}(\mathrm{S})$, respectively; see Fig. $1 \mathrm{~B}]$, shown by the primer extension stops at $\mathrm{Bl}(\mathrm{L})$ and $\mathrm{B} 1(\mathrm{~S})$, is increased in the

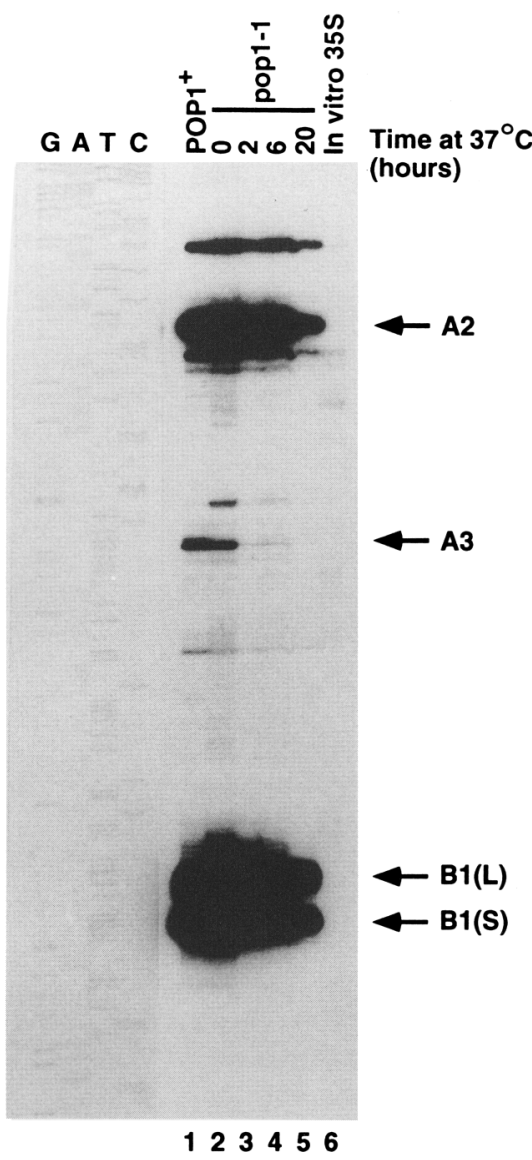

Figure 3. Primer extension through pre-rRNA cleavage site $\mathrm{A} 3$ in POP1 and pop1-1 strains. (Lane 1) RNA extracted from a wild-type $P O P 1^{+}$strain following growth at $37^{\circ} \mathrm{C}_{;}$(lane 2) RNA extracted from a pop 1-1 strain following growth at $23^{\circ} \mathrm{C}_{j}$ (lanes 3-5) RNA extracted from a pop1-1 strain following growth at $37^{\circ} \mathrm{C}$ for the times indicated; (lane 6) pre-rRNA transcribed in vitro. Primer extension was performed using oligonucleotide $\mathrm{d}$, which hybridizes to the $5^{\prime}$ region of ITS1 (see Fig. 1). Primer extension stops at sites $\mathrm{A} 2, \mathrm{~A} 3, \mathrm{~B} 1(\mathrm{~L})$, and $\mathrm{B} 1(\mathrm{~S})$, corresponding to the $5^{\prime}$ ends of the $27 \mathrm{SA}, 27 \mathrm{SA}^{\prime}, 27 \mathrm{SB}(\mathrm{L})$, and $27 \mathrm{SB}(\mathrm{S})$ prerRNAs, respectively, are indicated. Sequencing reactions on the rDNA with the same primer are also shown.

pop1-1 strain grown at $37^{\circ} \mathrm{C}$ (data not shown). This parallels the increase in the ratio of the mature $5.8 \mathrm{~S}(\mathrm{~L})$ to $5.8 \mathrm{~S}(\mathrm{~S})$.

Synthesis of the 27SA' pre-rRNA was also examined in an rrp2-1 strain (Shuai and Warner 1991; generously provided by J. Warner), which carries a mutation in the RNA component of RNase MRP (Chu et al. 1994). Strains carrying $\operatorname{rrp2-1}$ or $\operatorname{rrp} 2-2$ are defective in the synthesis of $5.8 \mathrm{~S}(\mathrm{~S})$ at $25^{\circ} \mathrm{C}$ but not at $18^{\circ} \mathrm{C}$ (Lindahl et al. 1992 ; Shuai and Warner 1991; data not shown). The synthesis of 27SA' pre-rRNA was therefore assessed by primer extension on RNA extracted following growth of the rrp2-1 strain at $18^{\circ} \mathrm{C}$ and $25^{\circ} \mathrm{C}$ (Fig. 4). The $27 \mathrm{SA}^{\prime}$ pre-rRNA is detected following growth of the rrp2-1 strain at $18^{\circ} \mathrm{C}$ (Fig. 4, lane 2) at a level similar to that in an $R R P 2^{+}$ 


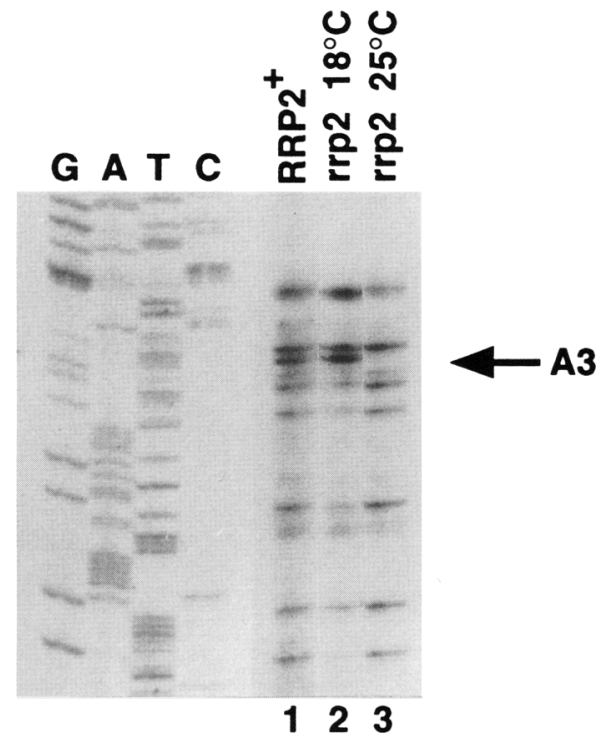

Figure 4. Primer extension through pre-rRNA cleavage site $A 3$ in RRP2 and rrp2-1 strains. (Lane 1) RNA extracted from a wildtype $R R P 2^{+}$strain following growth at $30^{\circ} \mathrm{C}$; (lane 2) RNA extracted from a rrp2-1 strain following growth at $18^{\circ} \mathrm{C}$; (lane 3 ) RNA extracted from a rrp2-1 strain following growth at $25^{\circ} \mathrm{C}$. Primer extension was performed using oligonucleotide $d$, which hybridizes to the $5^{\prime}$ region of ITS1 (see Fig. 1). The primer extension stop at site A3, corresponding to the $5^{\prime}$ end of the $27 \mathrm{SA}^{\prime}$ pre-rRNA, is indicated. Sequencing reactions on the rDNA with the same primer are also shown.

strain (Fig. 4, lane 1). Following growth of the rrp2-1 strain at $25^{\circ} \mathrm{C}$, no $27 \mathrm{SA}^{\prime}$ pre-rRNA can be detected (Fig. 4, lane 3). The level of premature primer extension stops because of secondary structure in the pre-rRNA, shown by their presence in RNA transcribed in vitro, is higher in the primer extension experiment shown in Figure 4 than in Figure 3. This variation may be attributable to the batch of reverse transcriptase used in the experiment (see also Henry et al. 1994). Other pre-rRNA processing reactions are not inhibited during growth of the rrp2-1 strain at $25^{\circ} \mathrm{C}$ (data not shown). Following incubation of the $\operatorname{rrp} 2-1$ strain at $37^{\circ} \mathrm{C}$, the nonpermissive temperature for growth, a more complex inhibition of pre-rRNA processing is seen (Shuai and Warner 1991; Lindahl et al. 1992; Schmitt and Clayton 1993; data not shown).

We conclude that cleavage of site $\mathrm{A} 3$ requires both the RNA component of RNase MRP and POPlp.

\section{POPl defines a single gene coding for an essential protein of $100 \mathrm{kD}$}

To determine whether the phenotype observed in the pop1-1 strain was attributable to a single mutation, this strain was backcrossed to a wild-type strain. The growth phenotype was found to be recessive to POP1 and, after sporulation and dissection of the diploid, the temperature sensitivity segregated $2: 2$ in the progeny. The temperature sensitivity and the defect in the synthesis of both 5.8S rRNA and tRNA (analyzed by Northern hybridization) were found to cosegregate in the progeny of four complete tetrads tested, making it likely that all of the observed phenotypes are the result of a single mutation.

The wild-type $P O P 1$ gene was cloned from a yeast genomic DNA library by complementation of the temperature sensitivity of the pop1-1 strain. Twelve complementing plasmids were recovered, all of which contained overlapping inserts derived from a single chromosomal locus. The restriction map of this locus and the position of the two least overlapping inserts are shown in Figure $5 \mathrm{~A}$. By subcloning from the original isolates, the complementing activity was localized to a $3.5-\mathrm{kb}$ fragment (Fig. 5A). Sequence analysis of this fragment revealed an open reading frame (ORF) of 876 amino acids, encoding a basic protein $(\mathrm{pI}=9.8$ ) of $100.5 \mathrm{kD}$ predicted molecular mass. The DNA sequence and the deduced amino acid sequence are shown in Figure 5B. Comparison of the DNA and protein sequences to the data bases revealed no significant homologies to any known proteins, and no motifs or repeats could be identified. The amino-terminal part of the protein is particularly basic and contains putative nuclear localization sequences.

Sequencing of the extremities of the original complementing clones revealed another putative ORF, upstream of the POP1 gene and transcribed in the opposite orientation. When compared with the Swissprot data base of protein sequences, this ORF shows high homology $(36-60 \%)$ to adenylosuccinate synthase from different organisms. In yeast, adenylosuccinate synthase is encoded by the ADE12 gene (Dorfman 1969), which maps to the left arm of chromosome XIV (Mortimer et al. 1992). While this work was in progress, the sequence of the $S$. cerevisiae $A D E 12$ gene was submitted to the EMBL data library. It overlaps our fully sequenced, 3.3$\mathrm{kb}$ fragment by 400 nucleotides. The position of the $A D E 12$ gene, with respect to the restriction map established for POP1, is shown on Figure 5A. On the basis of the linkage to the $A D E 12$ gene, we conclude that the POP1 gene is localized on the left arm of chromosome XIV.

To demonstrate that the cloned DNA contained the wild-type allele of pop1-1 and not an extragenic suppressor, the LEU2 gene was targeted to the chromosomal locus of the cloned fragment in a wild-type haploid strain (see Materials and methods). Correct integration of the marker was verified by Southern analysis. The resultant strain was crossed to pop 1-1 and analyzed by segregation. This revealed complete cosegregation of the LEU2 marker with the wild-type POP1 for nine complete tetrads tested, demonstrating tight linkage between the cloned POP1 gene and the temperature-sensitive lesion.

A null allele of $P O P 1$ was constructed by replacing the 766 amino-terminal amino acids of POP1 with the TRP1 gene. The resultant pop1::TRP1 gene was used to transform two diploid strains to Trp prototrophy. Insertion at the POP1 locus was confirmed by Southern analysis. From each of these strains, 22 tetrads were dissected. Each tetrad yielded only two viable spores, and none of 
A
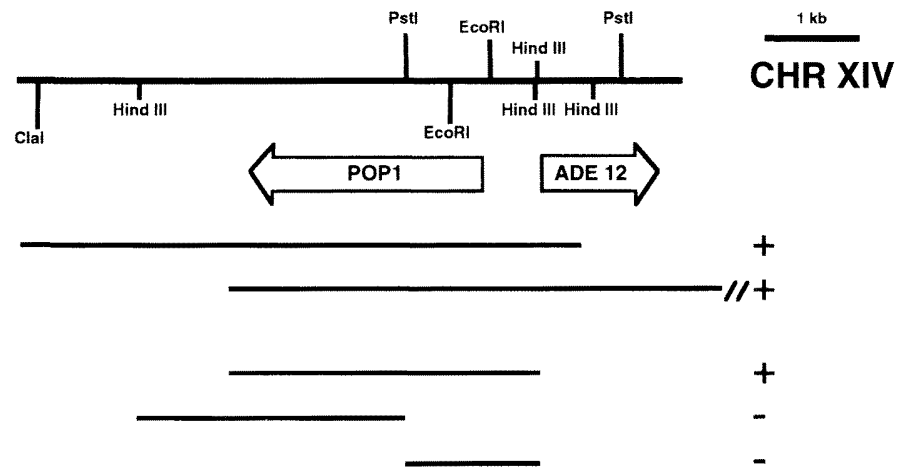

B

Figure 5. $(A)$ Restriction map of the chromosomal locus containing the POP1 gene. The position and direction of transcription of the POP1 and ADE12 ORFs are indicated. The extent of the two least overlapping complementing fragments recovered and of three subclones constructed to localize the gene are shown below the map. $1+1$ Subcloned regions that complement the pop1-1 mutation; $(-1$ those that failed to complement. $(B)$ Nucleic acid and deduced protein sequence of the POP1 gene. The restriction sites $X b a \mathrm{I}$ and $B s t$ EII used for the gene disruption are underlined.

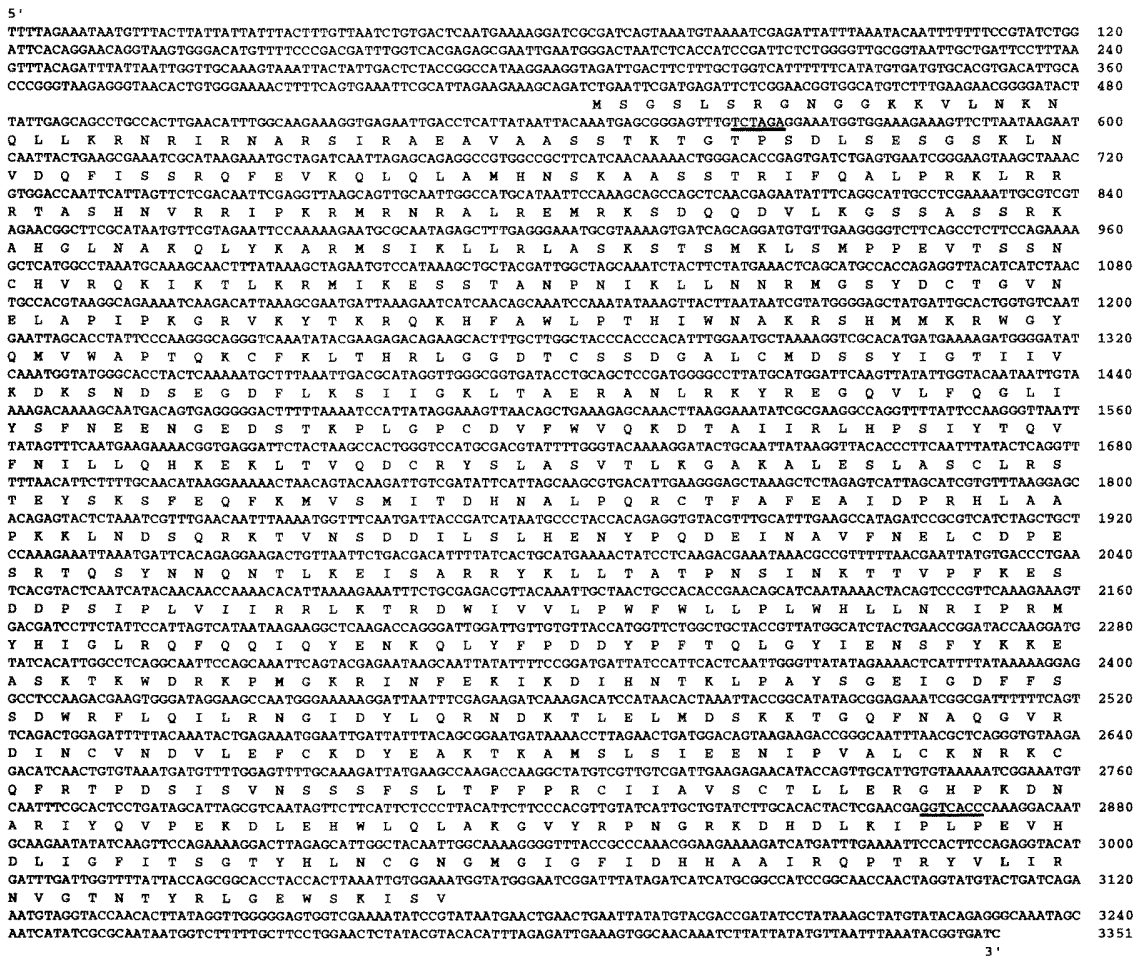

the viable spores carried the pop $1:: T R P$ marker, establishing that POP1 is an essential gene.

\section{popl-1 strains underaccumulate the RNase $P$ and RNase MRP RNAs}

The effects of incubation of the pop1-1 strain at the nonpermissive temperature on the accumulation of the RNA components of RNase P and RNase MRP were assessed by Northern hybridization (Fig. 6). RNA was extracted from the POP1 strain (Fig. 6, lane 1) and from the pop1-1 strain following growth at $23^{\circ} \mathrm{C}$ (Fig 6, lane 2) or after transfer to $37^{\circ} \mathrm{C}$ for 2,6 , or $20 \mathrm{hr}$ (Fig. 6, lanes 3-5). The steady-state level of the MRP RNA falls during growth of the pop1-1 strain at $37^{\circ} \mathrm{C}$. The steady-state level of the mature RNase P RNA also falls at $37^{\circ} \mathrm{C}$. In contrast, the $5^{\prime}+3^{\prime}$ extended form of the RNase P RNA (visible as a larger band in Fig. 6) is less strongly reduced. This would be consistent with this RNA representing a precursor that continues to be synthesized while the mature RNase P RNA is destabilized by the inactivation of POPlp. It is notable that the level of the RNase MRP and the mature RNase P RNAs is not strongly reduced until $6 \mathrm{hr}$ of growth at $37^{\circ} \mathrm{C}$. In contrast, the inhibition of $\mathrm{A} 3$ cleavage (Fig. 3) and accumulation of pre-tRNA (Fig. 2) is seen after $2 \mathrm{hr}$ of growth at $37^{\circ} \mathrm{C}$. It is therefore unlikely that the rapid initial loss of RNase P and RNase MRP activity is attributable to the reduced levels of the RNA components. The levels of the snoRNAs, snR30, U3, snR10 (Fig. 6), U14, and the U1 snRNA (data not shown) are not altered during growth of the pop1-1 strain at $37^{\circ} \mathrm{C}$. The POPlp is therefore required to maintain the 


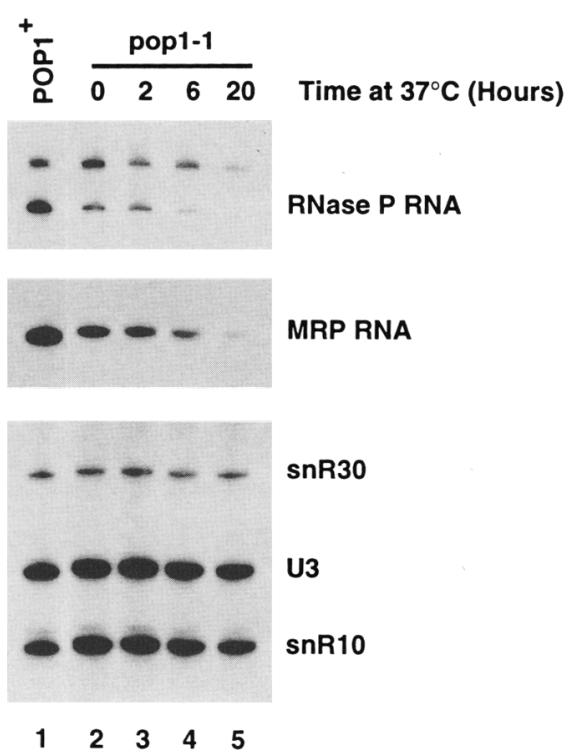

Figure 6. Levels of the RNase $P$ and RNase MRP RNAs in pop1-1 strains. (Lane 1) RNA extracted from a wild-type $P O P 1^{+}$ strain following growth at $37^{\circ} \mathrm{C}$; (lane 2) RNA extracted from a pop1-1 strain following growth at $23^{\circ} \mathrm{C}$; (lanes 3-5) RNA extracted from a pop1-1 strain following growth at $37^{\circ} \mathrm{C}$ for the times indicated. RNA was separated on a polyacrylamide gel and transferred for Northern hybridization. RNA extracted from $0.1 \mathrm{OD}_{600}$ unit of cells $\left(\sim 2 \times 10^{6}\right.$ cells $)$ was loaded in each lane. Hybridizing RNAs are indicated; the upper band on the RNase P RNA panel is the $5^{\prime}$ and $3^{\prime}$ extended species, which may be a precursor to the mature RNase P RNA.

steady-state levels of both RNase MRP and the mature RNase P RNAs.

\section{RNase $P$ and RNase MRP RNAs coprecipitate with a ProtA-POP1 fusion protein}

To test for the direct association of POPlp with the RNA components of RNase P and RNase MRP, we constructed an epitope-tagged POP1 protein. Two IgG-binding domains from the Staphylococcus aureus protein A were fused in-frame to POPlp at either the amino-terminal (ProtA-POP1) or the carboxy-terminal (POP1ProtA) end. These constructs, on a single-copy plasmid, where used to transform a pop1::TRP1/POP1 diploid heterozygous for the POP1 deletion. After sporulation and dissection, spores disrupted for POP1 but carrying the ProtA-POP1 fusion protein were viable and exhibited no growth defect, showing that the amino-terminal fusion protein is fully functional. In contrast, no progeny carrying pop $1:: T R P 1$ and complemented by the POP1ProtA construct were obtained from the dissection of 22 tetrads, and the carboxy-terminal fusion protein therefore appears not to be functional.

Interaction of POPlp with the RNase P and RNase MRP particles was tested by immunoprecipitation (Fig. 7). Whole cell extracts were prepared from two different strains expressing the ProtA-POPl protein fusion in a
pop1::TRP1 genetic background (Fig. 7, lanes $3,4,7,8$, and 11,121 , and as controls, extracts from a wild-type strain (Fig. 7, lanes 2,6,10) and a strain expressing a fusion protein between protein $\mathrm{A}$ and the $70-\mathrm{kD}$ U1 snRNP protein (Fig. 7, lanes 1,5,9) were used. The extracts were immunoprecipitated using IgG-agarose /see Materials and methods |, and RNA was recovered from the total extract (Fig. 7, lanes 1-4), from the supernatant (Fig. 7, lanes 5-8), and from the immunoprecipitates (Fig. 7, lanes 9-12). RNAs from equivalent quantities of each fraction were analyzed by Northern hybridization (Fig. 7) and primer extension (data not shown). The RNA components of both RNase P and RNase MRP are recovered very efficiently in the immunoprecipitates from the strains expressing ProtA-POP1 (Fig. 7, lanes 11,12) but not from the control strains (Fig. 7, lanes 9,10). Greater than $90 \%$ of both RNAs can be coprecipitated with ProtA-POP1. For RNase P RNA, the mature RNA and

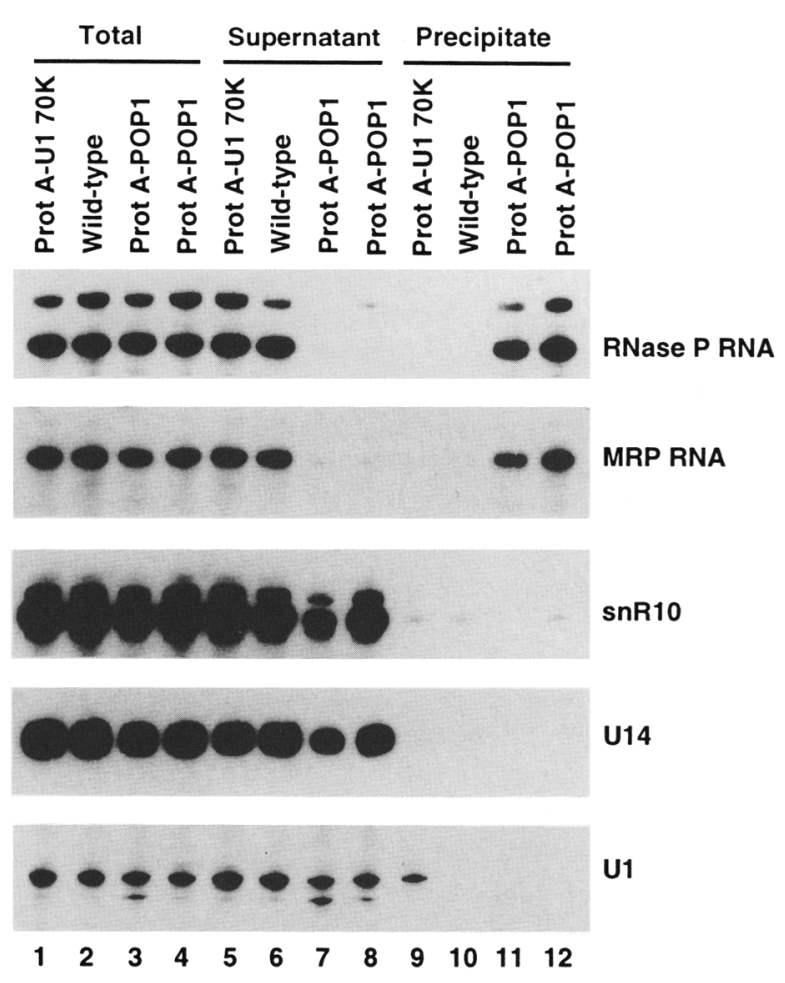

Figure 7. Coprecipitation of the RNase P and RNase MRP RNAs with POPlp. (Lanes 1-4) Total RNA from cell lysates; (lanes 5-8) RNA recovered from the immunesupernatants; (lanes 9-12) RNA recovered from the immunoprecipitates; (lanes 1,5,9) Wild-type strain of yeast; (lanes 2,6,10) Strain expressing a protein A-U1 70K protein fusion; (lanes $3,4,7,8,11$, and 12) Strains expressing the ProtA-POPl fusion. IgG agarose was used to immunoprecipitate the protein A fusions from whole cell lysates. RNA was recovered from the immunesupernatants and immunoprecipitates, and from equivalent aliquots of the total lysates, separated on a polyacrylamide gel, and transferred for Northern hybridization. Hybridizing RNAs are indicated; the upper band on the RNase P RNA panel is the 5' and $3^{\prime}$ extended species, which may be a precursor to the mature RNase P RNA. 
the larger, putative precursor RNA are immunoprecipitated with similar efficiencies. Other snoRNAs, snR10, U14 (Fig. 7), U3, and snR30 (data not shown), are not detectably immunoprecipitated. The U1 snRNA is not coprecipitated with ProtA-POP1 (Fig. 7, lanes 11,12), but is coprecipitated with the ProtA-U1 $70 \mathrm{~K}$ fusion protein (Fig. 7, lane 9).

From these experiments we conclude that POPlp is a component of both the RNase P and RNase MRP particles.

\section{Discussion}

\section{POP1 is a component of RNase P and RNase MRP}

We have isolated a mutation in a novel gene, $P O P 1$, from a bank of temperature-sensitive-lethal yeast mutants. The mutant allele, pop1-1, inhibits both the pre-rRNA processing pathway leading to the synthesis of the $5.8 \mathrm{~S}$ rRNA and the processing of pre-tRNAs. The coprecipitation of the RNA components of RNase P and RNase MRP with ProtA-POP1, together with the loss of these RNAs on growth of the pop1-1 strain at nonpermissive temperature, demonstrates that POPlp is a component of both RNPs.

Bacterial RNase P consists of an RNA and a single protein. The proteins, cloned from different bacterial species, are small and basic but show only limited sequence conservation (for review, see Altman et al. 1993). Some homology can be found between conserved residues in the bacterial RNase P proteins and sequences in POP1p, but it is unclear whether this is significant given the overall basic character of these proteins. Highly purified RNase P from the fission yeast $S$. pombe also contains a single protein (Zimmerly et al. 1993), of $100 \mathrm{kD}$ estimated molecular mass. The similarity between this estimate and the size of POPlp (100.5 kD) suggests that this $S$. pombe protein is the homolog of POPlp. A protein component of the $S$. cerevisiae mitochondrial RNase $\mathrm{P}$, encoded by the RPM2 gene, has also been characterized (Morales et al. 1992; Dang and Martin 1993). This protein has a molecular mass of $105 \mathrm{kD}$ and is essential for mitochondrial RNase $\mathrm{P}$ function in vivo but has no significant homology to POPlp. The protein composition of RNase $\mathrm{P}$ and RNase MRP from higher eukaryotes is less well defined, but they may share a protein of $40 \mathrm{kD}$, referred to as the Th protein /Gold et al. 1989; Yuan et al. 1989; Karwan 1993). The Th protein has not been sequenced or cloned but may have epitopes in common with the bacterial RNase P proteins, as antibodies against the $E$. coli protein cross-react with a 40 $\mathrm{kD}$ protein component of human RNase $\mathrm{P}$ (Mamula et al. 1989), which may well be the Th protein. The buoyant density reported for human RNase P (Bartkiewicz et al. 1989 ) and the sedimentation velocity of the RNase MRP (Karwan 1993) would not be consistent with the presence of only the RNA and a protein of $40 \mathrm{kD}$, indicating that other protein components are likely to be present. POPlp is the first nuclear RNase P and the only RNase MRP protein for which the gene has been cloned. It is not clear whether POPlp is the homolog of the Th antigen or represents a different common component.

Incubation of pop1-1 strains at the restrictive temperature leads to a decrease in the levels of the mature RNase $P$ and RNase MRP RNAs, whereas the longer, putative precursor of RNase $P$ RNA is much less affected. The fact that both forms of the RNase P RNA coprecipitate with the ProtA-POP1 fusion protein shows that POPlp binds efficiently to the longer as well as to the shorter RNase P RNA. POP1 protein binding might stabilize the mature RNase P and RNase MRP RNAs. Alternatively, binding of POP1p to the RNase P RNA precursor could be required for maturation to occur. It is not unusual for RNP proteins to be involved in the maturation or stability of their respective RNAs. In higher eukaryotes, the common U-snRNP Sm proteins are required for modification and transport of the newly synthesized snRNPs (for review, see Mattaj et al. 1993), and in $S$. cerevisiae, the protein components of the U4/U6 and U4/U6/U5 spliceosomal snRNPs, PRP3, PRP4, PRP6, and PRP24 contribute to U6 snRNA stability (Blanton et al. 1992).

\section{POP1p is required for RNase $P$ and RNase MRP function}

The pop1-1 mutation inhibits the function of RNase P and RNase MRP in vivo. Mutations in the RNA components of both RNase P and RNase MRP also inhibit enzymatic activity in vivo, and the combined phenotypes of these mutations resemble very closely that of the pop1-1 mutation. These RNPs therefore appear to require both RNA and protein components for function. The function of the snRNAs and snoRNAs studied to date also requires an association with the cognate proteins to produce an RNP complex. In E. coli, the RNase $P$ protein $(C 5)$ is required for the function of the RNP in vivo. $\mathrm{C} 5$ plays a role in the binding of at least some substrates (Peck-Miller and Altman 1991) and in release of the product, and also improves the discrimination between binding to the substrate and product (Reich et al. 1988; Tallsjö and Kirsebom 1993; for review, see Altman et al. 1993|. In addition, binding of the protein in vitro can suppress mutations in the RNase P RNA /Lumelsky and Altman 1988), indicating that it can alter the structure of the RNA. It has been proposed that a protein component of the $S$. cerevisiae RNase $P$ plays a role in substrate binding (Nichols et al. 1988) and the $100-\mathrm{kD}$ protein that copurifies with the $S$. pombe RNase P activity can interact specifically with the pre-tRNA substrate (Zimmerly et al. 1993).

The kinetics of the inhibition of processing following transfer of pop1-1 strains to the nonpermissive temperature shows that loss of enzymatic activity is not attributable to the underaccumulation of the RNAs. Cleavage of $\mathrm{A} 3$ is lost within $2 \mathrm{hr}$ of transfer to nonpermissive temperature, and clear accumulation of pre-tRNA is also seen at this time. In contrast, the levels of the RNase P and RNase MRP RNAs are not strongly reduced at this time. It remains possible that the pop1-1 mutation re- 
sults in the mislocalization of the RNPs at the nonpermissive temperature, but it is more likely that POP1p has a direct role in catalysis, either by altering the conformation of the RNase P and RNase MRP RNAs or by binding directly to the substrates. The role of POPlp in binding to the pre-tRNA and/or pre-rRNA substrates can now be tested.

\section{A requirement for $R$ Nase MRP RNA and POP1p for A3 cleavage}

The processing of the $35 \mathrm{~S}$ rRNA precursor involves a series of cleavage steps that finally generate the mature forms of the 18S, 5.8S, and $25 \mathrm{~S}$ rRNAs (see Fig. 1B). Cleavage of the yeast pre-rRNA at different processing sites shows distinct requirements for RNPs. The early cleavages at sites $\mathrm{A} 0, \mathrm{~A} 1$, and $\mathrm{A} 2$ require the activities of the essential snoRNAs, U3, U14, and snR30, together with their associated proteins, fibrillarin (NOP1), SOF1p, and GARlp (for review, see Fournier and Maxwell 1993). However, no mutations in these components have been found to impair cleavage at site A3 (Henry et al. 1994). In contrast, we have shown here that cleavage of the prerRNA at site A3 requires another RNP complex, the MRP RNA and POP1 protein. Cleavage at site A3 has been shown to be required as an entry site for the exonucleases that generate the $5^{\prime}$ end of the $5.8 \mathrm{~S}(\mathrm{~S})$ but is not required for the synthesis of $5.8 \mathrm{~S}(\mathrm{~L})$ (see Fig. 1B) (Henry et al. 1994). Consistent with these results, the rrp2-1 (Shuai and Warner 1991; Lindahl et al. 1992; Schmitt and Clayton 1993) and pop1-1 mutants are both inhibited in cleavage at $\mathrm{A} 3$ and underaccumulate $5.8 \mathrm{~S}(\mathrm{~S})$. In contrast, the level of the $5.8 \mathrm{~S}(\mathrm{~L})$ rRNA is mildly increased in these mutants. In pop1-1 strains, cleavage at site $\mathrm{A} 3$ is absent $2 \mathrm{hr}$ after temperature shift, before other pre-rRNA processing defects are evident and well before any growth defect is observed. This makes it probable that RNase MRP is directly responsible for A3 cleavage in vivo. RNase MRP has been purified from vertebrates and yeast using an assay for the in vitro cleavage of the cognate mitochondrial RNA sequences at the site of priming for DNA replication (Chang and Clayton 1987; Stohl and Clayton 1992). The sequence surrounding A3 is not clearly homologous to this site, perhaps reflecting differences between the specificity of RNase MRP in vitro and in vivo.
The cleavage at site $\mathrm{A} 3$ by RNase MRP plays a crucial role in the synthesis of yeast 5.8S rRNA. All of the available evidence shows that the processing of yeast and vertebrate pre-rRNAs is highly conserved. It will therefore be of interest to determine whether RNase MRP cleavage sites also lie upstream of vertebrate $5.8 \mathrm{~S}$ rRNA genes.

\section{Materials and methods}

Strains and media

Growth and handling of $S$. cerevisiae and E. coli was by standard techniques. Table 1 lists the yeast strains used in this study.

\section{Mutagenesis}

A haploid yeast strain (BSY295) was grown to saturation and washed once with water, and appropriate dilutions were plated on YPD plates to a density of 3000 cells/plate. The plates were irradiated using the Stratalinker (Stratagene) at a dose of $1.8 \mathrm{~mJ}$ that results in 5-15\% survival. Plates were incubated in the dark for 3 days, and the surviving colonies were replicated at $15^{\circ} \mathrm{C}, 23^{\circ} \mathrm{C}$, and $37^{\circ} \mathrm{C}$ to test for temperature and cold sensitivity. Putative temperature-sensitive and cold-sensitive strains were colony purified and retested for growth at different temperatures and for the loss of specific markers. Of $12.5 \times 10^{3}$ surviving colonies 246 temperature-sensitive strains $(2 \%)$ and 129 cold-sensitive strains $(1 \%)$ were isolated; the rate of loss of different markers was in the range of $1.5-2 \%$.

\section{Cloning of POP1}

To clone the POP1 gene, the pop1-1 temperature-sensitive strain was transformed with a genomic $S$. cerevisiae library in pUN100 (Bergës et al. 1994), and cells were directly selected for growth at $37^{\circ} \mathrm{C}$. Twelve colonies growing at $37^{\circ} \mathrm{C}$ were picked, and all were shown to contain a plasmid. Plasmids were recovered in $E$. coli, and restriction map analysis of the inserts showed that they fell into five overlapping groups, ranging in size from 5.5 to $10.5 \mathrm{~kb}$ and deriving from the same part of the yeast genome. To localize further the complementing activity, a 3.5-kb HindIII-Sacl fragment, representing the smallest region present in all clones and two further subclones (a 1.5- and a 2.5-kb HindIII-Pst I fragment; see Fig. 4A) were cloned into vector pRS415 (Sikorski and Hieter 1989) and tested for complementation of pop1-1 temperature sensitivity. The $3.5-\mathrm{kb}$ HindIII-SacI fragment was the minimal complementing subclone.

Both strands of the $3.5-\mathrm{kb}$ HindIII-SacI fragment were se-

Table 1. Yeast strains

\begin{tabular}{|c|c|}
\hline Strain & Genotype \\
\hline BSY295 & MATa, ura3-52, arg4, leu2-3, 112, ade2, TRP1::SNR14-t ${ }^{\mathrm{a}}$ \\
\hline BSY360 & MAT $\alpha$, ura3-52, his3- $\Delta 1$, leu2-3, 112, ade2, ade5, TRP1::SNR14-t ${ }^{\mathrm{a}}$ \\
\hline BSY413 & MATa, ura3-52, his3- $\Delta 1$, leu2-3, 112, ade2, arg4, trp1-289, pop1::TRP1 [pRS415, ProtA-POP1] \\
\hline BSY414 & MATa, ura3-52, arg4, leu2-3, 112, ade2, trp1-289, pop1::TRP1 [pRS415, ProtA-POP1] \\
\hline BSY19 & 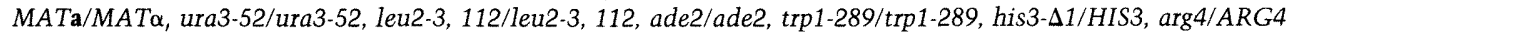 \\
\hline BSY20 & MATa/MAT $\mathbf{\alpha}$, ura3-52/ura3-52, arg4/arg4, leu2-3, 112/leu2-3, 112, ade2/ade2, trp1-289/trp1-289 \\
\hline BSY409 & 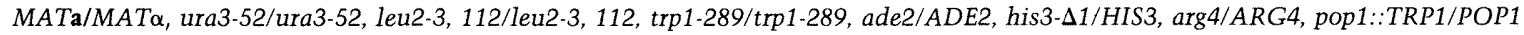 \\
\hline BSY410 & MATa/MATa, ura3-52/ura3-52, arg4/arg4, leu2-3, 112/leu2-3, 112, ade2/ade2, trp1-289/trp1-289, pop1::TRP1/POP1 \\
\hline
\end{tabular}

${ }^{2} \mathrm{SNR} 14-\mathrm{t}$ is a copy of the $\mathrm{U} 4$ snRNA gene under the control of the GAL10 regulatory sequences and bearing a neutral tag. 
quenced (Sanger et al. 1977) from the original as well as smaller subclones using vector and internal oligonucleotide primers.

To establish linkage of the cloned genomic fragment to pop11 , one of the originally recovered plasmids, containing a $5.5-\mathrm{kb}$ insert, was digested with $X$ hoI and SalI and religated to remove the CEN-ARS part of the pUN100 vector. The plasmid derived was linearized with $B g I I I$ and used to transform a wild-type haploid yeast strain (BSY360). Insertion of the LEU2 marker at the correct chromosomal location was verified by Southern analysis. The strain was mated to pop 1-1, the diploid was sporulated, and the segregation pattern of $L E U 2$ and temperature sensitivity was monitored.

To construct a POP1 null allele, a 2.3-kb XbaI-BstEII fragment containing most of the POP1 ORF was replaced by a 854 bp EcoRI-BgIII, Klenow-treated fragment containing the TRP1 ORF. In the clone selected, TRP1 would be transcribed in the opposite orientation to POP1. A 3.5 -kb linear fragment containing the pop1::TRP1 allele was excised by digestion with ClaI and SpeI and used to transform two wild-type diploid strains (BSY19 and BSY320). TRP ${ }^{+}$transformants were tested for correct integration events by Southern analysis. The heterozygous POP1/pop1::TRP1 diploids obtained (BSY409 and BSY410) were sporulated and dissected. In all 22 tetrads dissected for each diploid, only two of four spores were viable and the growing colonies were always $\operatorname{trp} 1$.

\section{Construction of the ProtA-POP1 fusion}

To construct a ProtA-POP1 fusion, a 395-bp fragment containing two IgG-binding domains of the $S$. aureus protein A was amplified by PCR from plasmid p28NZZtrc (see Grandi et al. 1993 ) and fused in-frame to the POP1-coding sequence either immediately before the first AUG (ProtA-POP1 fusion) or at the carboxyl terminus of $P O P 1$, after amino acid 775 of the predicted POP1 ORF (POP1-ProtA fusion). The original POP1 promoter and 3 '-flanking sequences were retained in these constructs. Both constructs were sequenced to confirm that no mutations were introduced during the PCR amplification steps.

The ProtA-POP1 and POP1-ProtA fusion genes in plasmid pRS415 were used to transform the heterozygous pop 1::TRP1/ POP1 diploids BSY409 and BSY410. Haploids containing pop1:: TRP1 complemented by the fusion gene were obtained only for the ProtA-POP1 construct (strains BSY413 and BSY414).

\section{Immunoprecipation of ProtA-POP1}

Yeast whole cell extracts were prepared essentially as described (Séraphin and Rosbash 1989). For the immunoprecipitations, 20 $\mu \mathrm{l}$ of a $50 \%$ solution of rabbit IgG agarose beads (Sigma A-2909) were washed three times in IPP 150 (150 mM NaCl, $10 \mathrm{~mm}$ Tris$\mathrm{HCl}$ at $\mathrm{pH} 8,0.1 \% \mathrm{NP}-40,0.1 \% \mathrm{NaN}_{3}$ ) and then added to $30 \mathrm{OD}$ equivalents of extract brought to $400 \mu \mathrm{l}$ in IPP150. After incubating for $2.5 \mathrm{hr}$ at $4^{\circ} \mathrm{C}$, the IgG pellets were washed four times with IPP150. The RNAs were extracted from the pellets by adding $400 \mu \mathrm{l}$ of proteinase $\mathrm{K}$ buffer $(100 \mathrm{mM}$ Tris- $\mathrm{HCl}$ at $\mathrm{pH} 7.5$, $125 \mathrm{~mm}$ EDTA at $\mathrm{pH} 8,150 \mathrm{mM} \mathrm{NaCl}, 1 \% \mathrm{SDS})$ and $20 \mu \mathrm{g}$ of $E$. coli tRNA as carrier. After three phenol/chloroform extractions, the RNAs were precipitated with ethanol.

\section{RNA extraction, primer extension, and Northern hybridization}

RNA was extracted as described previously (Tollervey and Mattaj 1987). Northern hybridization (Tollervey 1987) and primer extension (Beltrame and Tollervey 1992) were as described previously. Oligonucleotide probes were used for pre-rRNA hybrid- ization and primer extension. Oligonucleotide a is ATGAAAACTCCACAGTG; oligonucleotide b is CCAGTTACGAAAATTCTTG; oligonucleotide $\mathrm{c}$ is TTTCGCTGCGTTCTTCATC ; oligonucleotide d is GGCCAGCAATTTCAAGT; and oligonucleotide e is AGATTAGCCGCAGTTGG. Oligonucleotide probes were also used for hybridization of tRNA. The mature tRNA ${ }_{3}^{\text {Leu }}$ probe was GCATCTTACGATACCTG; the 5'flanking sequence probe was CCAAACAACCACTTATTTGTTGA; the intron probe was CACAGTTAACTGCGGTC; the mature tRNA ${ }^{\text {AlaUGC }}$ probe was CTACCAACTGCGCCATG; the mature tRNA ${ }^{G l y G C C}$ probe was TACCACTAAACCACTAGC; the mature tRNA ${ }^{\text {ProugG }}$ probe was ACCCAGGGCCTCTCG; and the mature tRNA ${ }^{\text {TrpCCA }}$ probe was AACCTGCAACCCTTCGA.

\section{Acknowledgments}

We thank Jonathan Warner for generously providing the rrp2-1 strain, Thierry Bergès for the yeast library, Paola Grandi for the protein A construct, and Kishore Sharma for assistance in hybridization with tRNA probes. We also thank the members of our laboratories and Iain Mattaj, Jaqueline Mermoud, and Mark Nichols for critical reading of the manuscript.

The publication costs of this article were defrayed in part by payment of page charges. This article must therefore be hereby marked "advertisement" in accordance with 18 USC section 1734 solely to indicate this fact.

\section{References}

Altman, S. 1989. Ribonuclease P: An enzyme with a catalytic RNA subunit. Adv. Enzymol. 62: 1-36.

Altman, S., L. Kirebom, and S. Talbot. 1993. Recent studies of ribonuclease P. FASEB /. 7:17-14.

Amberg, D.C., A.L. Goldstein, and C.N. Cole. 1992. Isolation and characterization of RAT1: An essential gene of Saccharomyces cerevisiae required for the efficient nucleocytoplasmic trafficking of mRNA. Genes \& Dev. 6: 1173-1189.

Bartkiewicz, M., H. Gold, and S. Altman. 1989. Identification and characterization of an RNA molecule that copurifies with RNase P activity from HeLa cells. Genes \& Dev. 3: 488-499.

Beltrame, M. and D. Tollervey. 1992. Identification and functional analysis of two U3 binding sites on yeast pre-ribosomal RNA. EMBO I. 11: 1531-1542.

Bergès, T., E. Petfalski, D. Tollervey, and E.C. Hurt. 1994. Synthetic lethality with fibrillarin identifies NOP77p, a nucleolar protein required for pre-rRNA processing and modification. $E M B O$ I. (in press).

Blanton, S., A. Srinivasan, and B. Rymond. 1992. PRP38 encodes a yeast protein required for pre-mRNA splicing and maintenance of stable U6 small nuclear RNA levels. Mol. Cell, Biol. 12: 3939-3947.

Chang, D.D. and D.A. Clayton. 1987. A novel endoribonuclease cleaves at a priming site of mouse mitochondrial DNA replication. $E M B O$ I. 6: 409-417.

Chu, S., R.H. Archer, J.M. Zengel, and L. Lindahl. 1994. The RNA of RNase MRP is required for normal processing of ribosomal RNA. Proc. Natl. Acad. Sci. 91: 659-663.

Côté, J. and A. Ruiz-Carrillo. 1993. Primers for mitochondrial DNA replication generated by endonuclease G. Science 261: 765-769.

Dang, Y.L. and N.C. Martin. 1993. Yeast mitochondrial RNase P. Sequence of the RPM2 gene and demonstration that its product is a protein subumit of the enzyme. $\%$. Biol. Chem. 268: 19791-19796. 
Darr, S.C., J.W. Brown, and N.R. Pace. 1992. The varieties of ribonuclease P. Trends Biol. Sci. 17: 178-182.

Dorfman, B. 1969. The isolation of adenylosuccinate synthetase mutants in yeast by selection for constitutive behavior in pigmented strains. Genetics 61: 377.

Fournier, M.J. and E.S. Maxwell. 1993. The nucleolar snRNAs: Catching up with the spliceosomal snRNAs. Trends Biol. Sci. 18: 131-135.

Gold, H.A., J.N. Topper, D.A. Clayton, and J. Craft. 1989. The RNA processing enzyme RNase MRP is identical to the Th RNP and related to RNase P. Science 245: 1377-1380.

Grandi, P., V. Doyl, and E.C. Hurt. 1993. Purification of NSP1 reveals complex formation with "GLFG" nucleporins and a novel nuclear pore protein NIC96. EMBO /. 12: 3061-3071.

Guerrier-Takada, C., K. Gardiner, T. Marsh, N.R. Pace, and S. Altman. 1983. The RNA moiety of RNase P is the catalytic subunit of the enzyme. Cell 35: 849-857.

Henry, Y., H. Wood, J.P. Morrissey, E. Petfalski, S. Kearsey, and D. Tollervey. 1994. The $5^{\prime}$ end of yeast $5.8 \mathrm{~S}$ rRNA is generated by exonucleases from an upstream cleavage site. EMBO J. 13: 2452-2463.

Karwan, R. 1993. RNase MRP/RNase P: A structure-function relation conserved in evolution. FEBS Lett. 319: 1-4.

Kiss, T., C. Marshallsay, and W. Filipowicz. 1992. 7-2/MRP RNA in plant and mammalian cells: Association with higher order structures in the nucleolus. EMBO J. 11: 37373746.

LaGrandeur, T.E., S.C. Darr, E.S. Haas, and N.R. Pace. 1993. Characterization of the RNase P RNA of Sulfolobus acidocaldarius. J. Bacteriol. 175: 5043-5048.

Lee, J.Y., C.E. Rohlman, L.A. Molony, and D.R. Engelke. 1991. Characterization of RPR1, an essential gene encoding the RNA component of Saccharomyces cerevisiae RNase P. Mol. Cell. Biol. 11: 721-730.

Lindahl, L., R.H. Archer, and J.M. Zengal. 1992. A new rRNA processing mutant of Saccharomyces cerevisiae. Nucleic Acids Res. 20: 295-301.

Lumelsky, N. and S. Altman. 1988. Selection and characterization of randomly produced mutants in the gene coding for the M1 RNA. J. Mol. Biol. 202: 443-454.

Mamula, M.J., M. Baer, J. Craft, and S. Altman. 1989. An immunological determinant of RNase P protein is conserved between Escherichia coli and humans. Proc. Natl. Acad. Sci. 86: $8717-8721$.

Mattaj, I.W., W. Boelens, E. Izaurralde, A. Jarmolowski, and C. Kambach. 1993. Nucleocytoplasmic transport and snRNP assembly. Mol. Biol. Rep. 18: 79-83.

Morales, M.J., Y.L. Dang, Y.C. Lou, P. Sulo, and N.C. Martin. 1992. A $105-\mathrm{kDa}$ protein is required for yeast mitochondrial RNase P activity. Proc. Natl. Acad. Sci. 89: 9875-9879.

Mortimer, R.K., R.C. Contopoulou, and J.S. King. 1992. Genetic and physical maps of Saccharomyces cerevisiae, edition 11 . Yeast 8: 817-902.

Nichols, M., D. Söll, and I. Willis 1988. Yeast RNase P: Catalytic activity and substrate binding are separate functions. Proc. Natl. Acad. Sci. 85: 1379-1383.

Nieuwlandt, D.T., E.S. Haas, and C.J. Daniels. 1991. The RNA component of RNase $P$ from the archaebacterium Haloferax volcanii. J. Biol. Chem. 266: 5689-5695.

Peck-Miller, K. and S. Altman. 1991. Kinetics of the processing of the precursor to $4.5 \mathrm{~S}$ RNA, a naturally occuring substrate for RNase P from Escherichia coli. J. Mol. Biol. 221: 1-5.

Potuschak, T., W. Rossmanith, and R. Karwan. 1993. RNase MRP and RNase P share a common substrate. Nucleic Acids Res. 21: 3239-3243.

Reich, C., G.J. Olsen, B. Pace, and N.R. Pace. 1988. Role of the protein moiety of RNase $\mathrm{P}$, a ribonucleoprotein enzyme. Science 239: 178-181.

Reimer, G., I. Raska, E.M. Tan, and U. Scheer. 1987. Human autoantibodies: Probes for nucleolus structure and function. Virchows Arch. B Cell Pathol. 54: 131-143.

Reimer, G., I. Raska, U. Scheer, and E.M. Tan. 1988. Immunolocalization of 7-2-ribonucleolprotein to the granular component of the nucleolus. Exp. Cell Res. 176: 117-128.

Rubin, G. 1974. Three forms of the 5.8S ribosomal RNA species in Saccharomyces cerevisiae. Eur. J. Biochem. 41: 197-202.

Sanger, F., S. Nicklen, and A.R. Coulson. 1977. DNA sequencing with chain-terminating inhibitors. Proc. Natl. Acad. Sci. 74: 5466-5467.

Schmitt, M.E. and D.A. Clayton. 1992. Yeast site-specific ribonucleoprotein endoribonuclease MRPcontains an RNA component homologous to mammalian RNase MRP RNA and essential for cell viability. Genes \& Dev. 6: 1975-1985.

- 1993. Nuclear RNase MRP is required for correct processing of pre-5.8S rRNA in Saccharomyces cerevisiae. Mol. Cell. Biol. 13: 7935-7941.

Schmitt, M.E., J.L. Bennett, D.J. Dairaghi, and D.A. Clayton. 1993. Secondary structure of RNase MRP RNA as predicted by phylogenetic comparison. FASEB $I$. 7: 208-213.

Séraphin, B. and M. Rosbash. 1989. Identification of functional U1 snRNA-pre-mRNA complexes committed to spliceosome assembly and splicing. Cell 59: 349-358.

Shuai, K. and J.W. Warner. 1991. A temperature sensitive mutant of S. cerevisiae defective in pre-rRNA processing. Nucleic Acids Res. 19: 5059-5064.

Sikorski, R.S. and P. Hieter. 1989. A system of shuttle vectors and yeast host strains designed for efficient manipulation of DNA is Saccharomyces cerevisiae. Genetics 122: 19-27.

Stohl, L.L. and D.A. Clayton. 1992. Saccharomyces cerevisiae contains an RNase MRP that cleaves at a conserved mitochondrial RNA sequence implicated in replication priming. Mol. Cell. Biol. 12: 2561-2569.

Tallsjö, A. and L.A. Kirsebom. 1993. Product release is a ratelimiting step during cleavage by the catalytic RNA subunit of Escherichia coil RNase P. Nucleic Acids Res. 21: 51-57.

Tollervey, D. 1987. A yeast small nuclear RNA is required for normal processing of pre-ribosomal RNA. EMBO I. 6: 41694175 .

Tollervey, D. and I.W. Mattaj. 1987. Fungal small nuclear ribonucleoproteins share properties with plant and vertebrate U-snRNPs. EMBO /. 6: 469-476.

Topper, J.N., J.L. Bennett, and D.A. Clayton. 1992. A role for RNase MRP in mitochondrial RNA processing. Cell 70: 1620.

Yuan, Y., R. Singh, and R. Reddy. 1989. Rat nucleolar 7-2 RNA is homologous to mouse mitochondrial RNase mitochondrial RNA-processing RNA. I. Biol. Chem. 264: 1483514839.

Zimmerly, S., D. Drainas, L.A. Sylvers, and D. Söll. 1993. Identification of a $100-\mathrm{kDa}$ protein associated with nuclear ribonuclease $\mathrm{P}$ activity in Schizosaccharomyces pombe. Eur. $J$. Biochem. 217: 501-507. 


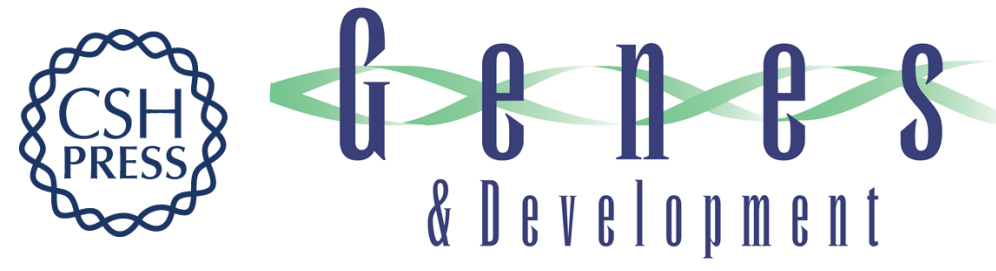

\section{The POP1 gene encodes a protein component common to the RNase MRP and RNase P ribonucleoproteins.}

Z Lygerou, P Mitchell, E Petfalski, et al.

Genes Dev. 1994, 8:

Access the most recent version at doi:10.1101/gad.8.12.1423

References This article cites 48 articles, 20 of which can be accessed free at:

http://genesdev.cshlp.org/content/8/12/1423.full.html\#ref-list-1

License

Email Alerting

Service

Receive free email alerts when new articles cite this article - sign up in the box at the top right corner of the article or click here.

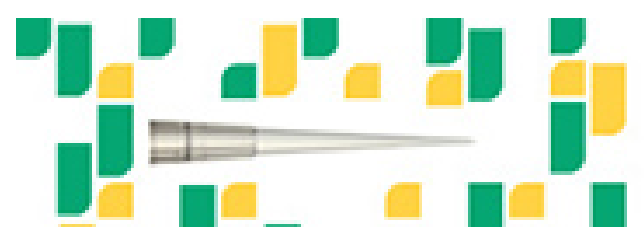

Focused on your science. 